\title{
Water Quality, Growth and Feed Efficiency of White Leg Shrimp (Litopenaeus vannamei) Co-Cultured with Red Seaweed (Gracilaria tenuistipitata) Under Partial Reduction of Feeding Rates
}

\author{
Nguyen Thi Ngoc Anh*, Nguyen Thanh Huu, Huynh Thanh Toi and Nguyen Minh Kha \\ College of Aquaculture and Fisheries, Can Tho University, Vietnam
}

Submission: November 25, 2019; Published: December 18, 2019

Corresponding author: Nguyen Thi Ngoc Anh, College of Aquaculture and Fisheries, Can Tho University, Campus II, 3/2 street, Ninh Kieu district, Can Tho city, Vietnam

\begin{abstract}
White-leg shrimp Litopenaeus vannamei juveniles $(0.95 \pm 0.03 \mathrm{~g}$ initial weight) and red seaweed Gracilaria tenuistipitata were co-cultured in 250-L tanks for 75 days. Five feeding treatments were performed, with the control group (monoculture) being fed a commercial shrimp feed at $100 \%$ feed ration ( $8 \%$ of biomass per day), while shrimp in the four other groups were co-cultured with red seaweed and received commercial feed at $85 \%, 70 \%, 55 \%$ and $40 \%$ of the feeding ration of the control. The results showed that the concentrations of the $\mathrm{TAN}, \mathrm{NO}_{2}^{-}, \mathrm{NO}_{3}^{-}, \mathrm{TN}$, $\mathrm{PO}_{4}{ }^{3}$-, TP, and COD in the co-culture tanks were significantly lower than in the monoculture. Survival, growth rates and production of the shrimp fed at $85 \%, 70 \%$ and $55 \%$ feed ration of the control were superior to those in the control group $(\mathrm{p}<0.05)$. Feed conversion ratio and feed cost were lower at the lower feeding rates and could be reduced from 45.3 to $65.9 \%$. Furthermore, proximate composition of shrimp meat such as moisture, protein and ash were similar among treatments except lipid content, which was significantly lower in co-culture than in monoculture. These results suggested that the co-culture of $L$. vannamei with $G$. tenuistipitata helped improve water quality, performances and feed efficiency of shrimp. Based on the survival, production and feed conversion ratio and feed cost data, it can be stated that shrimp co-cultured with red seaweed applied $55 \%$ feeding rate could be the optimal feeding level.
\end{abstract}

Keywords: Co-culture; Litopenaeus vannamei ; Gracilaria tenuistipitata; Water quality; Survival; Growth; Feed efficiency; Production; Shrimp coloration; Proximate composition.

\section{Introduction}

Shrimp is the most important internationally traded fishery commodity in terms of value. Asia is predominant in the shrimp sector of which shrimp farming in Vietnam is fast growing and making the country the third-highest level shrimp exporter globally [1]. White leg shrimp (Litopenaeus vannamei) is one of important cultured species in the region. However, rapid growth of intensive shrimp farming has been leading to negative environmental impacts in both short term and long term with ecological imbalance, pollution, disease outbreak [1,2]. Moreover, feed cost occupies large proportion in the intensive shrimp farming, accounted for more than $50 \%$ of production cost $[3,4]$. Therefore, the sustainable development of shrimp farming requires responsible practices to improve their operating efficiency and help minimize environmental degradation of coastal ecosystems $[1,2,5]$. Seaweeds are most suitable for bio-filtration because they probably have the highest productivity of all plants.
There is potential with some culture systems to integrate seaweed culture with other forms of aquaculture to make better use of marine resources and reduce the impacts of more intensive forms of aquaculture [6-8].

Red seaweeds (Gracilaria spp.) are important and commercially valuable resource for the industrial use (agar extraction) and human food, traditional medicine and animal feed. Additionally, Gracilaria species have been used as biofilter in aquaculture system $[9,10]$. G. cervicornis could serve as a partial substitute for the industrial feeds used in L. vannamei shrimp farming [11]. Co-culturing the black tiger shrimp (Penaeus monodon) with $G$. tenuistipitata improved water quality and feed efficiency [12]. Recently, red seaweed (G. tenuistipitata) has been found abundantly in the improved extensive shrimp farms from Bac Lieu and Ca Mau provinces of the Vietnamese Mekong delta, and is believed to be good for fish and shrimp [13]. This study was 
carried out to evaluate the effects of reduction in feeding rate on water quality, growth and feed efficiency of the white leg shrimp (L. vannamei) co-cultured with red seaweed (G. tenuistipitata) in tanks conditions. The results could provide scientific and practical information for application of this model in shrimp farming that contribute to reduce feed cost and minimize environmental impact.

\section{Materials and Methods}

\section{Experimental Design}

The experiment was conducted for a period of 75 days at the College of Aquaculture and Fisheries, Can Tho University, Vietnam. Five feeding treatments were randomly designed in triplicate tanks. Shrimps were monocultured and fed commercial feed (CF) at $100 \%$ feed ration, with $8 \%$ of biomass per day as control treatment, while shrimp in the other four treatments were co-cultured with red seaweed and fed at rates of $85 \%, 70 \%, 55 \%$ and $40 \%$ feed ration of the control, as follows:

- Shrimp_monoculture_100\% feed ration (Control)

- Shrimp + G. tenustipitata_85\% feed ration of control $(\mathrm{G}+80 \% \mathrm{C})$

- Shrimp + G. tenustipitata _70\% feed ration of control $(\mathrm{G}+60 \% \mathrm{C})$

- $\quad$ Shrimp + G. tenustipitata _55\% feed ration of control $(\mathrm{G}+40 \% \mathrm{C})$

- Shrimp + G. tenustipitata _40\% feed ration of control $(\mathrm{G}+20 \% \mathrm{C})$

\section{Experimental System and Management}

The experimental system was set up under a transparent roof with a natural photoperiod (light intensity fluctuated between 4,500 and 17,500 lux during the daytime). Juvenile shrimps with a mean initial weight of $0.95 \pm 0.03 \mathrm{~g}$ (obtained from previous experiment) were reared at a density of 150 ind. $\mathrm{m}^{-3}$ in $200-\mathrm{L}$ tanks (30 ind. tank ${ }^{-1}$ ) with water salinity of $10 \mathrm{~g} \mathrm{~L}^{-1}$. All culture tanks were provided with continuous aeration to maintain dissolved oxygen levels of 5-6 mg L-1. For co-culture treatments, red seaweed was placed in each tank at a rate of $2 \mathrm{~kg} \mathrm{~m}^{-3}$ and the biomass of red seaweed was monitored every 15 days. Shrimps were fed commercial Vannamei shrimp feed (GROBEST, Grobest \& I-MEI Company, Dong Nai province, Vietnam) four times a day at $6: 00,11: 00,16: 00$ and 21:00 h. For the control treatment, shrimp were fed at $100 \%$ feed ration ( $8 \%$ of the biomass per day) and feeding was slightly adjusted daily based on the presence or absence of residual feed to avoid overfeeding.

In other treatments, the feeding regimes were allocated with a gradual reduction of feeding rates based on the feed ration of the control treatment. Water exchanges were done biweekly with approximately $50 \%$ of the tank volume. The experiment lasted for 75 days. Red seaweed G. tenuistipitata was collected from the improved extensive farm in Bac Lieu province. After collection, red seaweed was separated from other seaweeds and acclimated to adapt to the experimental salinity $\left(10 \mathrm{gL}^{-1}\right)$ in a $2 \mathrm{~m}^{3}$ tank for 7 days. The proximate composition of red seaweed and commercial feed is presented in Table 1 .

Table 1: Proximate composition (\% dry weight) of red seaweed and commercial feed used in this study.

\begin{tabular}{|c|l|l|l|l|}
\hline Proximate composition & \multicolumn{1}{|c|}{ Moisture } & Protein & Lipid & \multicolumn{1}{c|}{ Fibh } \\
\hline Red seaweed & $84.32 \pm 1.63$ & $20.41 \pm 0.34$ & $1.55 \pm 0.11$ & $24.07 \pm 0.51$ \\
\hline Grobest feed* & $\leq 11$ & $\geq 40$ & $\geq 6.58 \pm 0.86$ \\
\hline
\end{tabular}

*: Information based on label from the manufacturer

\section{Data Collection}

\section{Water Quality}

Temperature, $\mathrm{pH}$, and DO were measured twice per day at 7:00 and 14:00 using a multi-channel meter (Mettler Toledo, USA), while alkalinity was determined weekly using a test kit (Sera, Germany). The concentrations of $\mathrm{NO}_{2}^{-}, \mathrm{NO}_{3}^{-}, \mathrm{PO}_{4}^{3-}$, the total amount of nitrogen in the forms of $\mathrm{NH}_{3}$ and $\mathrm{NH}_{4}$ in water (TAN), the total nitrogen (TN), and the total phosphorus (TP) were analyzed every 15 days using the standard method of APHA (1998) [14].

\section{Growth Performances}

The initial and final as well as intermediate samples were taken to measure average individual weight to determine growth rates of shrimp. Sampling was done at a 15-day interval. Ten shrimps in each tank were randomly taken and weighed in groups using an electronic balance with an accuracy of $0.01 \mathrm{~g}$ and then the shrimps were returned to the original tanks. At the end of experiment, all shrimp was individually weighed and the survival was calculated. Growth data for experimental shrimps included weight gain (WG), daily weight gain (DWG), specific growth rate in weight (SGR), survival, feed conversion ratio (FCR), and total feed cost, which were calculated using the following equations:

- Weight gain $(\mathrm{g})$ = final weight - initial weight

- $\quad$ DWG $\left(\right.$ g day $\left.^{-1}\right)=($ final weight - initial weight $) /$ cultured days $\mathrm{x} 100$

- $\quad(\mathrm{SGR})\left(\% \mathrm{day}^{-1}\right)=((\ln$ final weight $)-(\ln$ initial weight $)) /$ cultured days $\mathrm{x} 100$

- $\operatorname{Survival}(\%)=$ final number of shrimp/initial number of shrimp x 100

- $\quad \mathrm{FCR}=$ feed provided (dry weight)/weight gain (wet weight)

- $\quad$ Total feed cost for $1 \mathrm{~kg}$ shrimp growth $\left(\mathrm{USD} \mathrm{kg}^{-1}\right)=$ feed price $x$ FCR 
At the end of the experiment, ten shrimps were randomly taken from each tank for the removal of shell and head, and samples were stored at $-15^{\circ} \mathrm{C}$. Moisture, crude protein, crude lipid, and ash in shrimp meat were analyzed according to the methods described by the Association of Official Analytical Chemists AOAC (2000) [15].

\section{Results and Discussion}

\section{Water Quality Parameters}

Table 2: Water temperature, $\mathrm{pH}$ and alkalinity in the culture tanks.

\begin{tabular}{|c|c|c|c|c|c|c|}
\hline \multicolumn{2}{|c|}{ Treatments } & Control & $\mathrm{G}+85 \% \mathrm{C}$ & $\mathrm{G}+70 \% \mathrm{C}$ & G+55\% C & $\mathrm{G}+40 \% \mathrm{C}$ \\
\hline \multirow{2}{*}{ Temperature $\left({ }^{\circ} \mathrm{C}\right)$} & 7:00 h & $26.6 \pm 0.9$ & $26.9 \pm 0.8$ & $26.9 \pm 0.7$ & $26.8 \pm 0.8$ & $26.7 \pm 0.9$ \\
\hline & 14:00 h & $28.7 \pm 1.1$ & $28.6 \pm 1.3$ & $28.9 \pm 1.2$ & $28.8 \pm 1.2$ & $28.6 \pm 1.1$ \\
\hline \multirow{2}{*}{ pH } & 7:00 h & $7.8 \pm 0.4$ & $7.9 \pm 0.2$ & $7.8 \pm 0.3$ & $7.9 \pm 0.3$ & $7.8 \pm 0.4$ \\
\hline & $14: 00 \mathrm{~h}$ & $8.1 \pm 0.3$ & $8.3 \pm 0.3$ & $8.2 \pm 0.2$ & $8.3 \pm 0.2$ & $8.2 \pm 0.4$ \\
\hline \multicolumn{2}{|c|}{ Alkalinity(mg CaCO3 L-1) } & $122 \pm 29$ & $121 \pm 24$ & $119 \pm 26$ & $126 \pm 20$ & $123 \pm 22$ \\
\hline
\end{tabular}

Daily water temperature and $\mathrm{pH}$ fluctuated in the ranges of $27.6-28.8^{\circ} \mathrm{C}$ and 7.8-8.3, respectively, and alkalinity concentrations between 119 and $126 \mathrm{mg} \mathrm{CaCO}_{3} \mathrm{~L}^{-1}$ throughout the experimental period (Table 2). Generally, these parameters did not much differ among treatments and remained within the suitable range for normal L. vannamei growth [16] and the development of red seaweed G. tenuistipitata [9]. The water quality in terms of nitrogen (TAN, $\mathrm{NO}_{2}^{-}, \mathrm{NO}_{3}^{-}$, and $\mathrm{TN}$ ) and phosphorus compounds $\left(\mathrm{PO}_{4}^{3-}\right.$ and $\left.\mathrm{TP}\right)$ are presented in Table 3. The concentrations of nitrogen and phosphorus compounds in the integration treatments were significantly lower $(p<0.05)$ than those in the monoculture. Furthermore, the concentrations of these compounds decreased at lower feeding rates. This indicated that red seaweed $G$. tenuistipitata may partly absorb the nitrogen and phosphorus compounds in the culture tanks, which helped to

\section{Statistical Analysis}

For all treatments, results were analyzed statistically with a one-way analysis of variance (ANOVA) to detect the overall effects of treatments (SPSS, version 16.0). Tukey's tests were used to identify significant differences between the mean values at a significant level of $p<0.05$. The percentage values were normalized through arcsine transformation before statistical analysis. improve water quality.

Previous investigations revealed that red seaweed Gracilaria species have been effectively used as a bio-filter in the integrated aquaculture systems, as they can absorb the ammonia, nitrate and phosphate that cause environmental pollution $[9,17]$. Other study confirmed that $G$. caudate can be co-cultured with shrimp in order to contribute to the removal of nitrogen and phosphorous from shrimp ponds [10]. Similarly, co-culture of $G$. corticata with L. vannamei decreased the levels of nitrogen and phosphorus in both water and sediments in L. vannamei culture [18]. Also, co-culturing black tiger shrimp (Penaeus monodon) with $G$. tenuistipitata helped to improve water quality [12]. The results of the present study are in accordance with the findings mentioned above. The co-culture of $L$. vannamei with $G$. tenuistipitata significantly improved the water quality in shrimp culture.

\section{Seaweed Biomass}

Table 3: Water quality parameters in the culture tanks.

\begin{tabular}{|c|c|c|c|c|c|}
\hline Treatments & Control & $\mathrm{G}+85 \% \mathrm{C}$ & $\mathrm{G}+70 \% \mathrm{C}$ & G+55\% C & $\mathrm{G}+40 \% \mathrm{C}$ \\
\hline TAN (mg L $\left.{ }^{-1}\right)$ & $0.76 \pm 0.05^{c}$ & $0.25 \pm 0.06^{b}$ & $0.18 \pm 0.05^{\mathrm{ab}}$ & $0.13 \pm 0.06^{\mathrm{a}}$ & $0.07 \pm 0.05^{\mathrm{a}}$ \\
\hline $\mathrm{NO}_{2}-\left(\mathrm{mg} \mathrm{L}^{-1}\right)$ & $1.10 \pm 0.24^{\mathrm{d}}$ & $0.53 \pm 0.18^{c}$ & $0.39 \pm 0.16^{b}$ & $0.31 \pm 0.15^{b}$ & $0.22 \pm 0.13^{\mathrm{a}}$ \\
\hline $\mathrm{NO}_{3}-\left(\mathrm{mg} \mathrm{L}^{-1}\right)$ & $1.72 \pm 0.28^{c}$ & $0.72 \pm 0.26^{b}$ & $0.66 \pm 0.27^{\mathrm{ab}}$ & $0.54 \pm 0.20^{\mathrm{ab}}$ & $0.43 \pm 0.14^{\mathrm{a}}$ \\
\hline TN $\left(\mathrm{mg} \mathrm{L}^{-1}\right)$ & $4.09 \pm 0.43^{c}$ & $1.51 \pm 0.61^{b}$ & $1.44 \pm 0.58^{\mathrm{b}}$ & $1.16 \pm 0.36^{\mathrm{ab}}$ & $0.95 \pm 0.14^{\mathrm{a}}$ \\
\hline $\mathrm{PO}_{4}{ }^{3-}\left(\mathrm{mg} \mathrm{L}^{-1}\right)$ & $1.03 \pm 0.15^{\mathrm{d}}$ & $0.41 \pm 0.13^{c}$ & $0.30 \pm 0.06^{\mathrm{b}}$ & $0.26 \pm 0.07^{\mathrm{ab}}$ & $0.17 \pm 0.08^{\mathrm{a}}$ \\
\hline $\mathrm{TP}\left(\mathrm{mg} \mathrm{L}^{-1}\right)$ & $1.38 \pm 0.45^{b}$ & $0.68 \pm 0.14^{\mathrm{a}}$ & $0.51 \pm 0.15^{\mathrm{a}}$ & $0.45 \pm 0.14^{\mathrm{a}}$ & $0.35 \pm 0.12^{\mathrm{a}}$ \\
\hline
\end{tabular}

Means with different superscripts in the same row are significantly different $(p<0.05)$ 


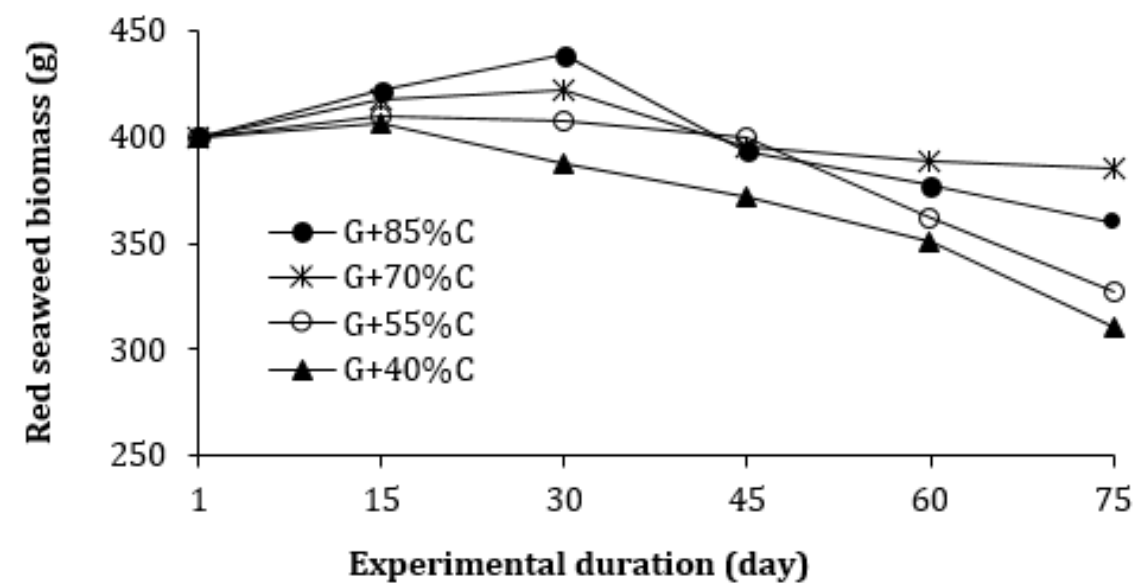

Figure 1: Biomass of $G$. tenuistipitata over experimental period.

Results showed that from day 15 to day 30, the biomass of red seaweed $G$. tenuistipitata in all integrated treatments slightly increased compared to the initial weight, except for the $\mathrm{G}+40 \% \mathrm{C}$ treatment, which showed a minute decrease. From day 45 onwards, seaweed biomass in all treatments gradually decline over time, of which the $\mathrm{G}+55 \% \mathrm{C}$ and $\mathrm{G}+40 \% \mathrm{C}$ showed sharp decrease in biomass at day 75 (Figure 1). This indicated that shrimp might consume red seaweed available in the culture tanks as supplemental feed to compensate for food shortage resulting in decreased in biomass in all co-culture treatments applied reducing feed rate. It was noted that the co-culture of shrimp and red seaweed significantly reduced the nitrogen and phosphorus concentrations in the culture tanks (as shown in Table 3) that indicated red seaweed absorbed nutrient released from shrimp waste for their growth, which helped to improve water quality.

\section{Growth, Feed Efficiency and Survival of Experimental Shrimp}

Figure 2 indicated that reduction of feeding rates influenced the individual weight of shrimp from day 30 onwards. At day 30, average values varied from 3.26-4.55 g, of which the smallest and largest shrimps were found in the $40 \%$ and $75 \%$ feeding ration groups, respectively. The control group received $100 \%$ feed ration attained intermediate growth and similar trend was observed until the end of experiment. Growth performance of shrimp after 75 days of culture was presented in Table 4. The final weight and weight gain (WG) of shrimps varied in the ranges of 7.84- $14.38 \mathrm{~g}$ and 6.90$13.43 \mathrm{~g}$, respectively, corresponding to daily weight gain (DWG) of 0.092-0.179 $\mathrm{g} \mathrm{day}^{-1}$ and specific growth rates (SGR) of $2.82-3.61 \%$ day $^{-1}$.

Table 4: Growth performances of experimental shrimp after 75 days of culture.

\begin{tabular}{|c|c|c|c|c|c|}
\hline Treatments & Control & G+85\%C & $\mathrm{G}+70 \% \mathrm{C}$ & G+55\% C & $\mathrm{G}+40 \% \mathrm{C}$ \\
\hline Initial weight (g) & $0.95 \pm 0.03$ & $0.95 \pm 0.03$ & $0.95 \pm 0.03$ & $0.95 \pm 0.03$ & $0.95 \pm 0.03$ \\
\hline Final weight (g) & $9.49 \pm 1.13^{\mathrm{b}}$ & $14.38 \pm 1.38^{\mathrm{d}}$ & $12.83 \pm 1.17^{c}$ & $12.23 \pm 0.99^{c}$ & $7.84 \pm 1.06^{\mathrm{a}}$ \\
\hline Weight gain (g) & $8.53 \pm 1.13^{b}$ & $13.43 \pm 1.38^{\mathrm{e}}$ & $11.89 \pm 1.17^{\mathrm{d}}$ & $11.29 \pm 0.99^{c}$ & $6.90 \pm 1.06^{\mathrm{a}}$ \\
\hline DWG (g day ${ }^{-1}$ ) & $0.114 \pm 0.015^{b}$ & $0.179 \pm 0.018^{\mathrm{d}}$ & $0.158 \pm 0.016^{c}$ & $0.151 \pm 0.013^{c}$ & $0.092 \pm 0.014^{\mathrm{a}}$ \\
\hline SGR $\left(\%\right.$ day $\left.^{-1}\right)$ & $3.045 \pm 0.16^{b}$ & $3.61 \pm 0.13^{\mathrm{d}}$ & $3.47 \pm 0.13^{c}$ & $3.41 \pm 0.11^{\mathrm{c}}$ & $2.82 \pm 0.18^{\mathrm{a}}$ \\
\hline Initial length $(\mathrm{cm})$ & $5.28 \pm 0.03$ & $5.25 \pm 0.03$ & $5.26 \pm 0.02$ & $5.22 \pm 0.03$ & $5.25 \pm 0.04$ \\
\hline Final length (cm) & $11.12 \pm 0.77^{\mathrm{b}}$ & $12.45 \pm 0.79^{\mathrm{d}}$ & $11.98 \pm 0.61^{\mathrm{cd}}$ & $11.71 \pm 0.66^{\mathrm{bc}}$ & $10.08 \pm 0.57^{\mathrm{a}}$ \\
\hline
\end{tabular}

Means with different superscripts in the same row are significantly different $(\mathrm{p}<0.05)$ 


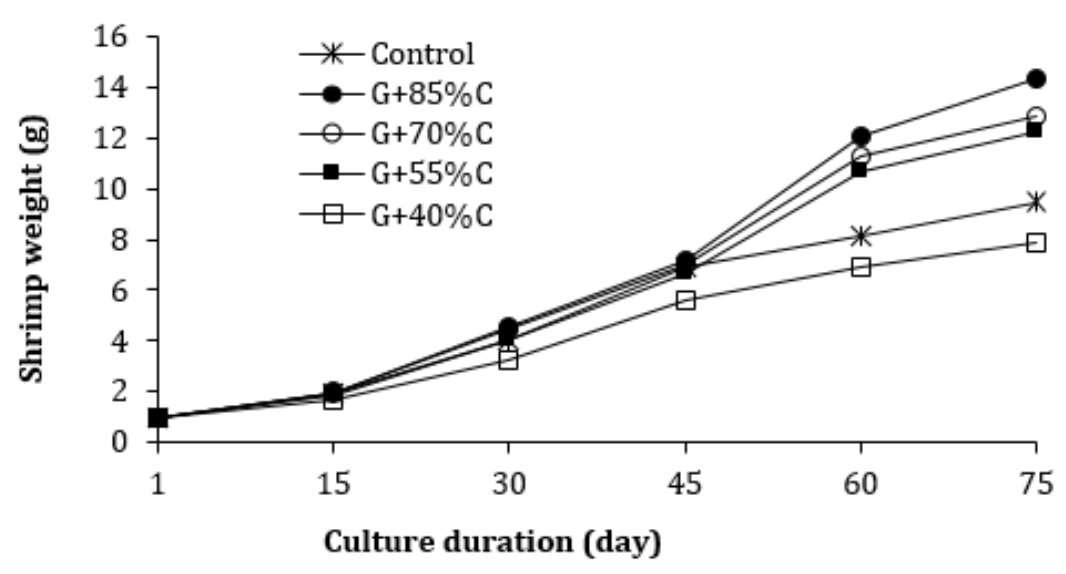

Figure 2: Growth curve of $L$. vannamei during culture duration.

The growth rate of shrimp in the $\mathrm{G}+85 \% \mathrm{C}, \mathrm{G}+70 \% \mathrm{C}$ and $\mathrm{G}+55 \% \mathrm{C}$ groups were significantly higher to that of the control treatment $(\mathrm{p}<0.05)$, while the $\mathrm{G}+40 \% \mathrm{C}$ group showed significantly poorer growth compared to the control group $(\mathrm{p}<0.05)$. Similar results was obtained for final length, which varied from 10.08 to $12.45 \mathrm{~cm}$. Statistical analysis indicated that shrimp growth in the $\mathrm{G}+85 \% \mathrm{C}$ and $\mathrm{G}+70 \% \mathrm{C}$ treatments were significantly $(\mathrm{p}<0.05)$ higher compared to the control and G+40\%C treatments. Overall, a gradual decrease in the growth performance of shrimp in coculture groups occurred with decreasing feeding ration.

\section{Survival, Productivity and Feed Efficiency}

At the end of experiment, the survival of shrimp ranged from $51.1 \%$ to $71.1 \%$ where control treatment was lowest and significantly different from the co-culture treatments. Comparing among integration groups, reduction of feeding rates did not affect survival of experimental shrimps ( $p>0.05)$. The average productivity of shrimp varied from 0.97 to $1.98 \mathrm{~kg} \mathrm{~m}^{-3}$, in which the values of the control and $\mathrm{G}+40 \% \mathrm{C}$ treatments were not significant differences $(p>0.05)$ and both were significantly $(p<0.05)$ lower than those in other treatments (Table 5). Feed conversion ratio (FCR) in groups receiving commercial feed (CF) tended to decline with the reduction of feeding rates. The control treatment obtained the highest FCR (1.76) and was significantly different $(p<0.05)$ from the remaining treatments. The lowest FCR (0.58) was found in the $\mathrm{G}+40 \% \mathrm{C}$ group, although it was not statistically different ( $p>0.05$ ) to the $\mathrm{G}+55 \%$ C group (Table 5).

Table 5: Survival, productivity and feed efficiency of shrimp after 75 days of culture

\begin{tabular}{|c|c|c|c|c|c|}
\hline Treatment & Survival (\%) & $\begin{array}{l}\text { Production } \\
\left(\mathrm{kg} \mathrm{m}^{-3}\right)\end{array}$ & FCR & $\begin{array}{l}\text { CF cost for shrimp growth } \\
\text { (USD kg-1) }\end{array}$ & $\begin{array}{c}\text { CF cost reduced versus } \\
\text { control }(\%)\end{array}$ \\
\hline Control & $51.1 \pm 5.1^{\mathrm{a}}$ & $0.97 \pm 0.12^{\mathrm{a}}$ & $1.76 \pm 0.06^{\mathrm{d}}$ & $2.93 \pm 0.09$ & - \\
\hline $\mathrm{G}+85 \% \mathrm{C}$ & $68.9 \pm 3.9^{b}$ & $1.98 \pm 0.08^{b}$ & $0.96 \pm 0.02^{c}$ & $1.60 \pm 0.03$ & $-45.3 \pm 1.1$ \\
\hline $\mathrm{G}+70 \% \mathrm{C}$ & $70.0 \pm 5.8^{b}$ & $1.80 \pm 0.13^{b}$ & $0.82 \pm 0.08^{b}$ & $1.37 \pm 0.14$ & $-53.3 \pm 4.7$ \\
\hline $\mathrm{G}+55 \% \mathrm{C}$ & $68.9 \pm 6.9^{b}$ & $1.69 \pm 0.16^{\mathrm{b}}$ & $0.60 \pm 0.04^{\mathrm{a}}$ & $1.01 \pm 0.06$ & $-65.9 \pm 2.1$ \\
\hline $\mathrm{G}+40 \% \mathrm{C}$ & $71.1 \pm 8.4^{b}$ & $1.12 \pm 0.13^{\mathrm{a}}$ & $0.58 \pm 0.04^{\mathrm{a}}$ & $0.96 \pm 0.06$ & $-67.2 \pm 2.0$ \\
\hline
\end{tabular}

Mean values with different superscripts in the same column are significantly different $(p<0.05)$

CF: commercial feed; price of commercial Grobest feed was 1.67 USD kg-1

The feed cost exhibited a similar pattern to that observed for FCR, with the highest feed cost observed in the control group $(2.93$ $\mathrm{USD} \mathrm{kg}^{-1}$ ), followed by the G+85\%C group (1.60 USD kg-1), which could decrease feed cost by $45.3 \%$. Furthermore, by reducing feed ration from $70 \%$ to $40 \%$, feed cost could be reduced from $53.3 \%$ to $67.2 \%$ compared to the control group. Generally, it can be stated that survival, production and feed utilization of shrimp in the $\mathrm{G}+55 \% \mathrm{C}$ group (received feeding rate of $55 \%$ feed ration

of the control) was better than that of the control group, and not statistical difference from the $\mathrm{G}+85 \% \mathrm{C} \mathrm{G}+70 \% \mathrm{C}$ groups (Table 5). This could be considered the optimal feeding rate in co-culture of L. vannamei with $G$. tenuistipitata. Several findings revealed that the presence of red seaweed Gracilaria species in shrimp ponds not only improved water quality but also enhanced the survival and growth of shrimp $[7,9,11,19]$. Besides serving as a bio-filter, Gracilaria served as a natural food source and shelter for fish 
and shrimp from predators as well as reduction of conspecific cannibalism of shrimp during molting $[2,9,19]$.

According to Marinho-Soriano et al. [11], seaweed G. cervicornis can partially substitute for the industrial feeds used in shrimp (L. vannamei) farming. Similarly, L. vannamei shrimp co-cultured with Sargassum polyphyllum or G. verrucosa attained better growth rate than those in monoculture [7]. Moreover, juvenile shrimp L. vannamei co-cultured with green seaweed Ulva clathrata reduced the need for artificial feed and improve shrimp quality [20]. The current result was similar to the study of Anh et al. [21], growth rate of shrimp L. vannamei in co-culture with green seaweed (Enteromorpha, Cladophoraceae)received 50\% and $75 \%$ feeding rations were equal to or significantly higher than shrimp fed to $100 \%$ feeding ration in monoculture, and FCR was reduced from $45.5 \%$ to $64.9 \%$ compared to monoculture. Moreover, co-culture of the black tiger shrimp (P. monodon)-red seaweed (G. tenuistipitata) and applied feeding rate from $50 \%$ to $75 \%$ satiation that improved water quality, survival, growth and feed cost was reduced from $40.41-62.96 \%$ compared to those in the monoculture [12].

\section{Proximate Composition of Shrimp}

The proximate analysis of fresh shrimp meat is shown in Table 6. The moisture contents of shrimp meat (water content of fresh shrimp meat), protein and ash were similar among treatments ( $p>0.05$ ) varying in the ranges of $75.62-76.05 \%, 18.03-18.92 \%$ and $1.56-1.87 \%$, respectively. The highest lipid content $(0.97 \%)$ was observed in shrimp fed $100 \%$ CF (control group), and significantly different from the other treatments $(\mathrm{p}<0.05)$. This content decreased with a decrease in feeding rate, with the lowest value $(0.68 \%)$ was observed in the $\mathrm{G}+40 \% \mathrm{C}$ group, however statistical difference was not found among the co-culture groups with reduction of feeding rates $(\mathrm{p}>0.05)$. These results support the investigation of other study, who found that feeding rates significantly affected the lipid content of $P$. monodon co-cultured with $G$. tenuistipitata, with higher lipid in shrimp meat being observed in the monoculture group received $100 \%$ feed ration [12]. Similarly, L. vannamei shrimp consumed green seaweed Ulva clathrata in co-culture tank that diminished lipids content in shrimp carcass and modified the fatty acids profile [20].

Table 6: Proximate composition of experimental shrimp (\% wet weight).

\begin{tabular}{|c|c|c|c|c|c|}
\hline Treatments & Control & $\mathrm{G}+85 \% \mathrm{C}$ & $\mathrm{G}+70 \% \mathrm{C}$ & $\mathrm{G}+55 \% \mathrm{C}$ & $\mathrm{G}+40 \% \mathrm{C}$ \\
\hline Moisture & $75.68 \pm 0.40^{\mathrm{a}}$ & $75.72 \pm 0.37^{a}$ & $75.62 \pm 0.27^{a}$ & $75.72 \pm 0.74^{\mathrm{a}}$ & $76.05 \pm 0.32^{\mathrm{a}}$ \\
\hline Protein & $18.16 \pm 0.38^{\mathrm{a}}$ & $18.92 \pm 0.15^{a}$ & $18.17 \pm 0.26^{\mathrm{a}}$ & $18.60 \pm 0.37^{\mathrm{a}}$ & $18.03 \pm 0.11^{\mathrm{a}}$ \\
\hline Ash & $1.56 \pm 0.08^{a}$ & $1.69 \pm 0.13^{\mathrm{a}}$ & $1.78 \pm 0.12^{\mathrm{a}}$ & $1.87 \pm 0.21^{\mathrm{a}}$ & $1.85 \pm 0.17^{\mathrm{a}}$ \\
\hline Lipid & $0.97 \pm 0.03^{b}$ & $0.82 \pm 0.04^{\mathrm{a}}$ & $0.81 \pm 0.04^{\mathrm{a}}$ & $0.75 \pm 0.06^{\mathrm{a}}$ & $0.68 \pm 0.03^{\mathrm{a}}$ \\
\hline
\end{tabular}

Mean values with different superscripts in the same row are significantly different $(p<0.05)$

\section{Conclusion}

The white leg shrimp L. vannamei co-cultured with red seaweed (G. tenuistipitata) and applied feeding rate from $55 \%$ to

\section{References}

1. Portley N (2016) Report on the shrimp sector: Asian shrimp trade and sustainability. Sustainable Fisheries Partnership.

2. Zhang Y, A Bleeker, J Liu (2015) Nutrient discharge from China's aquaculture industry and associated environmental impacts. Environmental Research Letter 10: 1-14.

3. Tacon A G J, D Jory, A Nunes (2013) Shrimp feed management: issues and perspectives. In: M R Hasan, M B New (eds). On-farm feeding and feed management in aquaculture, FAO Fisheries and Aquaculture Technical Paper No. 583, Rome, pp. 481-488.

4. Hung L T O M Quy (2013) On farm feeding and feed management in whiteleg shrimp (Litopenaeus vannamei) farming in VietNam. In: M R Hasan, M B New (eds.) On-farm feeding and feed management in aquaculture. FAO Fisheries and Aquaculture Technical Paper No. 583, Rome, pp. 337-357.

5. Anh P T, C Kroeze, S R Bush, A P J Mol (2010) Water pollution by intensive brackish shrimp farming in south-east Vietnam: Causes and options for control. Agricultural Water Management 97(6): 872-882.

6. Troell M, A Joyce, T Chopin, A Neori, A H Buschmann, J G Fang (2009) Ecological engineering in aquaculture - Potential for integrated multi-
$80 \%$ satiation that significantly improved water quality, survival, growth, production and feed efficiency of shrimp compared to those in the monoculture.

trophic aquaculture (IMTA) in marine offshore systems. Aquaculture 297(1-4): 1-9.

7. Susilowati T, Hutabarat J, Anggoro S, Zainuri M (2014) The improvement of the survival, growth of naname shrimp (Litopenaeus vannamei) and seaweed (Gracilaria verucosa) based on polyculture cultivation. IJMARCC 1: 6-11.

8. Samocha T M, J Fricker, A M Ali, M Shpigel, A Neori (2015) Growth and nutrient uptake of the macroalga Gracilaria tikvahiae cultured with the shrimp Litopenaeus vannamei in an integrated multi-trophic aquaculture (IMTA) system. Aquaculture 446 (1): 263-271.

9. Peng C, S Hong-Bo, X Di, Q Song (2009) Progress in Gracilaria biology and developmental utilization: Main Issues and Prospective. Reviews in Fisheries Science 17(4): 494-504.

10. Marinho-Soriano E, S O Nunes, M A A Carneiro, D C Pereira (2009) Nutrients' removal from aquaculture wastewater using the macroalgae Gracilaria birdiae. Biomass and Bioenergy 33(2): 327-331.

11. Marinho-Soriano E, M R Camara, T D M Cabral, M A D A Carneiro (2007) Preliminary evaluation of the seaweed Gracilaria cervicornis (Rhodophyta) as a partial substitute for the industrial feeds used in shrimp (Litopenaeus vannamei) farming. Aquaculture Research 38(2): 182-187. 
12. Anh N T N, L T H Ngan, N H Vinh, T N Hai (2018) Co-culture of red seaweed (Gracilaria tenuistipitata) and black tiger shrimp (Penaeus monodon) with different feeding rations. International Journal of Scientific and Research Publications 8(9): 269-277.

13. Vinh N H, N T N Anh (2019) Study on abundance of red seaweed (Gracilaria tenuistipitata) in the improved- extensive shrimp farms from Bac Lieu and Ca Mau provinces. Science and Technology Journal of Agriculture and Rural Development 1: 88-97.

14. APHA (1998) Standard methods for the examination of water and wastewater. The Association, Washington, DC.

15. AOAC (2000) Official Methods of Analysis. Association of Official Analytical Chemists Arlington.

16. Chakravarty M S, P R C Ganesh, D Amarnath, B S Sudha, T S Babu (2016) Spatial variation of water quality parameters of shrimp (Litopenaeus vannamei) culture ponds at Narsapurapupeta, Kajuluru and Kaikavolu villages of East Godavari district, Andhra Pradesh. International Journal of Fisheries and Aquatic Studies 4(4): 390-395

17. Abreu M H, R Pireira, Ch Yarish, A H Buschmann, I S Pinto (2011) IMTA with Gracilaria vermiculophylla: Productivity and nutrient removal performance of the seaweed in a land- based pilot scale system. Aquaculture 312(1-4): 77-78.

18. Fourooghifard H, A Matinfar, M S Mortazavi, K R Ghadikolaee, R M Ghadikolaee (2018) Nitrogen and phosphorous budgets for integrated culture of white leg shrimp Litopenaeus vannamei with red seaweed Gracilaria corticata in zero water exchange system. Iranian Journal of Fisheries Sciences 17(3): 471-486.

19. Andayani S, R Yuwanita, N Izzah (2016) Biofilter application using seaweed (Gracillaria verucosa) to increase production of Vannameil shrimp in traditional pond district Bangil-Pasuruan. Research Journal of Life Science 3(1):16-22.

20.Cruz-Suárez L, E A León, A Peña-Rodríguez, G Rodríguez-Peña, B Moll, et al. (2010) Shrimp/Ulva co-culture: A sustainable alternative to diminish the need for artificial feed and improve shrimp quality. Aquaculture 301(1-4): 64-68.

21. Anh N T N, D T K Nhung, T N H Hai (2014) Feed efficiency of white leg shrimp (Litopeneaus vannamei) in co-culture with gut weed (Enterormorpha sp.) and blanket weed (Cladophoraceae). Scientific Journal of Can Tho University, Vietnam 31b: 98-105.

This work is licensed under Creative

Commons Attribution 4.0 Licens

DOI: 10.19080/OFOAJ.2019.11.555813

\section{Your next submission with Juniper Publishers} will reach you the below assets

- Quality Editorial service

- Swift Peer Review

- Reprints availability

- E-prints Service

- Manuscript Podcast for convenient understanding

- Global attainment for your research

- Manuscript accessibility in different formats ( Pdf, E-pub, Full Text, Audio)

- Unceasing customer service

Track the below URL for one-step submission https://juniperpublishers.com/online-submission.php 